\title{
Jurisdictional Fetter on the FTC
}

The Federal Trade Commission is charged with protecting the public from unfair or deceptive business practices. ${ }^{1}$ If a firm engages in an illegal practice, the Commission may forbid its continued use through an enforceable order to cease and desist. ${ }^{2}$ The Commission has found that the only economical method of enforcement is to seek voluntary compliance on an industry-wide basis. ${ }^{3}$ The industry-wide voluntary compliance program is in effect an informal, governmentally im-

1. Federal Trade Commission $\S 5(\mathrm{a})(6), 15$ U.S.C. $\S 45(\mathrm{a})(6)$ (1964). This Act, hcrcinafter referred to as the FTC Act, was enacted in 1914. FTC Act, ch. 311, 38 Stat, 719 (1914).

2. FTC Act $\S 5(\mathrm{~b}), 15$ U.S.C. $\S 45(\mathrm{~b})(1964)$. Section 5 of the Act makes illegal "unfair methods of competition in commerce and unfair or deceptive acts or practices in commerce," (hereinafter referred to as unfair acts in commerce). "Unfair or deceptive acts or practices in commerce" were added as categories of illegality in 1938. FTC Act $\S 5$, ch. 49, 52 Stat. 111 (1938). Unfair acts in commerce "does not "admit of precise definition, . . . [its] meaning ... must be arrived at by . .. "the gradual process of judicial inclusion and exclusion." "FTC v. R. F. Keppel \& Bro., 291 U.S. 304, 312 (1934). Unfair acts include unethical practices, $i d$. at 313 , as well as practices which tend to hinder competition or create a monopoly, id. at $310-13$. While most if not all the activitics prohibited by the Sherman, Clayton, and Robinson-Patman Acts are also unfair acts (cf. $i d$. at $310 \mathrm{n} .1$ ), this Note is primarily concerned with jurisdiction over those unfair acts not otherwise pro. hibited by federal law. See note 80 infra. These include fraudulent or misleading ad. vertising, sales techniques, and packaging and the use of lottery devices in the sale of merchandise. See, e.g., FTC v. Colgate-Palmolive Co., 380 U.S. 374, 386.87 (1965); FTC v. R. F. Keppel \& Bro., 291 U.S. 304 (1934); Holland Furnace Co. v. FTC, 269 F.2d 203 (7th Cir. 1959), cert. denied, 361 U.S. 932 (1960), aff'd on rehearing, 295 F.2d 302 (7th Cir. 1961).

The Commission is directed to issue a complaint if it has reason to believe that an unfair act has been committed, that it was committed "in commerce," and that a procecl. ing would be in the public interest. FTC Act $\S 5(\mathrm{~b}), 15$ U.S.C. $\S 45(\mathrm{~b})$ (1964). If the case is contested, a formal hearing takes place, FTC Act \& 5(b), I5 U.S.C. \& 45(b) (1964), gencrally conducted by a hearing examiner, FTC Rules of Practice \$ 3, 16 C.F.R. \& 3 (Supp. 1966). The hearing examiner files an initial opinion containing findings of law and fact and, if the requisite findings as to the commission of an unfair act in commerce and public interest are made, issues an initial order to cease and desist. Id. $\S 3.21$ (b), 16 C.F.R. $\S 3.21$ (b) (Supp. 1966). Unless a seasonal appeal to the full Commission is filed by the respondent or the Commission qua complainant, the initial order becomes final. Id. \$\$ 3.21 (a), $8.22,16$ C.F.R. $\$ \S 3.21$ (a), 3.22 (Supp. 1966). On appeal, the Commission may adopt, modify, or set-aside the initial opinion and order. Id. \$ 3.24, 16 C.F.R. \$ 3.24 (Supp. 1966). Unless the respondent takes seasonal appeal from the disposition of the Commission, its order bc. comes final. FTC Act $\$ 5(\mathrm{~g})$, 15 U.S.C. $\$ 45(\mathrm{~g})$ (1964). If the respondent violates a final orter, he may be made to pay a civil penalty of up to $\$ 5,000$ for each violation, each day of a continuing violation being a separate violation. FTC Act $\S 5(1), 15$ U.S.C. $\S 45(1)(1964)$.

3. Address by Paul Rand Dixon, Chairman of the FTC, before the Division of Food, Drug, and Cosmetic Law of the American Bar Association, in Montreal, Aug. 10, 1966. "The very volume of American business would utterly and hopelessly inundate any simple cops-and-robbers effort by the FTC." $I d$. 8. When "as frequently happens, the illegality spreads beyond a manageable toehold, ... for the FTC to crack down on it with formal action would put too great a strain on the Commission's resources" Id. 11 (emphasis added). " $[T]$ he 'whipping boy' technique has severe limitations, the principal onc being that too often equally culpable competitors are not at all dismayed to see the whipping boy slowly tied up by a formal cease-and-desist order while they continue to profit by the same illegality. If they interpret government's action as 'handwriting on the wall for' their own sins, they are slow readers." Id. 7. 
posed cartel enforced through the threat of cease and desist orders." As such, it has curbed many undesirable business practices "without the expense, delay and unavoidable competitive inequities incident to individual formal complaint proceedings."

The industry-wide voluntary compliance program is obviously clumsy and ineffectual without jurisdiction over all important competitors in a market. ${ }^{6}$ Yet, since it was held in FTC v. Bunle Bros. that Congress did not intend to grant jurisdiction over local activities which affect but are not in interstate commerce, ${ }^{7}$ local firms are unregulable even where they compete with interstate concerns. This Note argues that Bunte Bros. should be limited to the extent necessary to allow the industry-wide voluntary compliance program to function effectively in policing interstate firms which compete with local firms. This can be done without giving the Commission the wide-ranging control of local business which would follow if its jurisdiction were made coterminous with the commerce power.

\section{The Statutory Language}

Under sections 4 and 5 of the Federal Trade Commission Act, a cease and desist order may issue only where a firm has engaged in an

unfair method of competition ... [or] unfair or deceptive acts or practices in commerce [among the several states]. ${ }^{8}$

The phrase "commerce among the several States" is borrowed from the commerce clause of the Constitution.

4. Id. 8-13. Having found that "most businessmen [wish] to keep their industries" practices clean," id. 8 , and that many violations "have been engendered and nourished by" competitive pressures," id. 10, the Commission cmploys industry-wide voluntary compliance in order "to provide business with the services it needs for more eftective sclfpolicing," id. 8.

Compliance programs typically begin with a survey of an industry and subsequent adoption by the Commission of trade practice rules and other guides which identify the kinds of business behavior which are regarded as violating the law. The Commission thereafter maintains close contact with the members of the industry to ensure that the rules and the industry-wide compliance program are understood. Past violators are asked to stipulate that they will comply with the law under the provisions of FIC Rules of Practice § 1.21, 16 C.F.R. § 1.21 (Supp. 1966). Report accompanying letter from Paul Rand Dixon, Chairman of the FTC, to Senator Warren Afagnuson, Dec 21, 1965, at 17-18. The Commission may also settle the case by asking violators to agree to a consent order which has the affect, inter se, of a final cease-and-desist order. FTC Rules of Practice $\$ 23,16$ C.F.R. \& 2.3 (Supp. 1966).

5. Report accompanying letter from Paul Rand Dixon, Chairman of the FTC, to Senator Warren Magnuson, Dec. 21, 1965, at 17.

6. Id. 15-16. See p. $1695-96$ infra.

7. FTC v. Bunte Bros., 312 U.S. 349 (1941) (6-3 decision).

8. FTC Act $\S 5,15$ U.S.C. $\S 45$ (1964). Bracketed material is taken from $\S 4$ of the FTC Act, 15 U.S.C. $\$ 44$ (1964), wherein "commerce" is defined as "commerce among the several States." 
The Congress shall have the power ... to regulate Commerce ... among the several States....

Nonetheless, the Act's language can be interpreted to give the Commission a jurisdiction narrower than that which Congress has the power to grant. ${ }^{9}$ According to this view, "commerce among the several States" means interstate commerce. ${ }^{10}$ As the words "in commerce among the several States" modify unfair act, the Commission may not regulate an unfair act in intrastate commerce merely because its perpetrator deals in interstate commerce ${ }^{11}$ or competes with interstate firms. ${ }^{12}$ Yet, Congress plainly could have granted jurisdiction over such unfair acts simply by using the words "affecting commerce" instead of "in commerce."13

According to another interpretation of "commerce among the several States" originating with Chief Justice Marshall, the words "in commerce" are sufficient to grant a jurisdiction coterminous with the commerce power. ${ }^{14}$ In this view, "commerce among the several States" encompasses "that commerce which concerns more states than one."15 Therefore, an unfair act not in the flow of interstate commerce is regulable if an effect on interstate commerce can be shown.

\section{FTC v. Bunte Bros.}

Although the Act was passed in 1914, it was not until 1941 that the Supreme Court in Bunte Bros. held that Congress intended "commerce among the several States" to be interpreted narrowly.10 Bunte Bros., a candy manufacturer, used an unfair method of sales promotion, but its sales were confined to one state, Illinois. The Commission did not urge, and had no grounds to urge, that the unfair acts were in interstate commerce. The Commission rather argued that the unfair acts were "in commerce" because they injured interstate commerce. ${ }^{17}$ Convincing evidence was adduced that Bunte Bros.' continued use of the unfair practice would directly and substantially reduce interstate candy manu-

9. See Stern, The Scope of the Phrase Interstate Commerce, 41 A.B.A.J. 823, 825, 873 (1955).

10. FTC v. Bunte Bros., 312 U.S. 349, 351 (1941).

11. Canfield Oil Co. v. FTC, 274 F. 571, 573-74 (6th Cir. 1921).

12. FTC v. Bunte Bros., 312 U.S. 349 (1941).

13. Id. at 355. In this view, Congress's power to regulate acts not in interstate commerce stems from the doctrine of implied powers or the "necessary and proper" clause. Stern, supra note 9 , at 826 .

14. Stern, supra note 9 , at 825 .

15. Gibbons v. Ogden, 22 U.S. (9 Wheat.) 1, 194 (1824).

16. FTC v. Bunte Bros., 312 U.S. $349,351,355$ (1941).

17. Brief for Appellant at 6, FTC v. Bunte Bros., 312 U.S. 349 (1941). 
facturers' sales in Illinois insofar as the Commission had ordered these interstate competitors to desist from the same unfair practice. ${ }^{18}$

The Court held that "in commerce among the several States" means "in interstate commerce," not "affecting commerce."10 Consequently, a mere effect on the sales of interstate competitors is not a sufficient basis upon which to predicate jurisdiction..$^{20}$ In finding that Congress had not exhausted its commerce power in its grant of jurisdiction, Mr. Justice Frankfurter, speaking for the Court, was swayed by a desire to preserve "the adjustment of local and national interests in our federal scheme." ${ }^{21}$ He feared that

The construction of $\S 5$ urged by the Commission would ... give a federal agency pervasive control over myriads of local businesses in matters heretofore traditionally left to local custom or local law.22

Therefore, Frankfurter urged a presumption against a federal law applying to local activities merely affecting interstate commerce not to be rebutted (1) without a clear manifestation of Congressional intent or (2) "unless ... the purpose of the act will [otherwise] be defeated."

The question of whether Congress had granted to the FTC jurisdiction over those local practices which injure interstate competitors had not reached the Court before Bunte Bros. largely because, earlier, it was not entirely clear that Congress itself had the power to grant such jurisdiction. ${ }^{24}$ But, from 1914, the year of the FTC Act ${ }^{25}$ and the Shreveport Rate Case, ${ }^{26}$ to 1941, the year of Bunte Bros. and United States v. Darby, ${ }^{27}$ the commerce power had gradually grown to reach acts affecting as well as acts in interstate commerce. ${ }^{8}$ Thus, although 19 of 20 previous cases treated jurisdiction as a constitutional question, ${ }^{29}$

18. FTC v. Bunte Bros., 312 U.S. 349, 355,357 (1941) (dissent).

19. FTC v. Bunte Bros., 312 U.S. 349,355 (1941).

20. Id. at 355 .

21. Id. at $\mathbf{3 5 1}$.

22. Id. at 354.

23. Id. at 351 .

24. Stern, supra note 9, at 825-26.

25. See note 2 supra.

26. Houston, E. \& W.T. Ry. v. United States, 234 U.S. 342 (1914).

27. 312 U.S. $100,118-24$ (1941).

28. Stern, supra note 9 , at 825-26.

29. In all cases previous to Bunte Bros, with the exception of California Rice Industry v. FTC, 102 F.2d 716, 718 (9th Cir. 1939), courts treated the jurisdictional question as a constitutional matter. They never raised the possibility that section 5 was not coterminous with the commerce power, they cited constitutional precedents, and they" denied jurisdiction only on the basis that the unfair acts were bejond the reach of the commerce power. See, e.g., FTC v. Pacific States Paper Trade Ass'n, 273 U.S. 52 (1927); General Motors Corp. v. FTC, 114 F.2d 33 (2d Cir. 1940), cert. denied, 312 U.S. 682 (1941); Chamber of Commerce of Minneapolis v. FTC, 13 F.2d 673 (8th Cir. 1926); Winslow v. 
Justice Frankfurter could consider their factual holdings reconcilable with Bunte Bros. ${ }^{30}$ Frankfurter concluded, in essence, that, without Congressional approval, judicial re-interpretation of the commerce clause ought not to lead to a concomitant increase in the jurisdiction of the Commission. ${ }^{31}$ Thus, Frankfurter seems to have adopted the traditional notions of the commerce clause of the earlier case law as a general theory of section 5 jurisdiction..$^{32}$

The distinction between "in interstate commerce" and "affecting interstate commerce" is a hard one to make and it is often blurred in constitutional decisions. ${ }^{33}$ Since intrastate acts which are $a$ part of an interstate transaction have long been considered in interstate commerce, ${ }^{34}$ "in interstate commerce" can mean "affecting interstate commerce" depending upon the meaning given to $a$ part of. ${ }^{35}$ The earlier cases held that when an unfair act was committed, its perpetrator's being engaged in interstate commerce did not place the unfair act itself "in interstate commerce." 36 Instead, the earlier cases focused on the origin of the goods involved in the unfair act. If the goods involved had not yet "come to rest" from their interstate journey, an unfair act within a single state was held to be $a$ part of an interstate transaction..$^{37}$ Thus, in dealing with unfair acts taking place wholly in one state, courts looked to whether the goods had "come to rest," not whether the perpetrator was engaged in interstate commerce.

\section{The Present Jurisdictional Test}

While in no case since 1941 has jurisdiction been asserted on theories contrary to Bunte Bros.' holding, courts have upheld the Commission on theories inconsistent with Bunte Bros.' general theory of section 5..$^{38}$ In Holland Furnace v. FTC and several other cases involving activities of local branches of firms with sales outlets in many states, courts have held that the Commission may regulate even those local branches which act in the capacity of a local retailer if their activities affect the firm's

FTC, 277 F. 206 (4th Cir. 1921); Canfield Oil Co. v. FTC, 274 F. 571 (6th Cir. 1921); Ward Baking Co. v. FTC, 264 F. 330 (2d Cir. 1920).

30. FTC v. Bunte Bros., 312 U.S. 349, 351-52, 352 n.3 (1941), and cases cited notc 29 supra.

31. FTC v. Bunte Bros., 312 U.S. 349, 355 (1941).

32. Id. at $351,352,352$ n.3.

33. Eiger, The Commerce Element in Federal Antitrust Litigation, 25 FrD. B.J. 282, 286.87 (1965).

34. FTC v. Pacific States Paper Trade Ass'n, 273 U.S. 52, 64 (1927); Chamber of Com. merce of Minneapolis v. FTC, 13 F.2d 673, 684 (8th Cir. 1926).

35. Eiger, supra note 33 , at 286-87.

36. Canfield Oil Co. v. FTC, 274 F. 571, 573-74 (6th Cir. 1921).

37. See cases cited note 34 supra.

38. Cases cited notes 39-41 infra. 
own interstate business. ${ }^{39}$ As jurisdiction is bottomed on the interstate nature of the perpetrator, 40 and on an "effect" on interstate commerce, 41 the conflict with Bunte Bros.' general theory of jurisdiction is clear. Holland Furnace, however, does not purport to overrule the holding of Bunte Bros. that jurisdiction may not be based on an effect on a competitor's interstate business. ${ }^{42}$ Nor does it purport to include within the Commission's jurisdiction unfair acts of a firm with sales outlets in only

39. Holland Furnace Co. v. FTC, 269 F.2d 203 (7th Cir. 1959), cert. denied, 361 U.S. 932 (1965), aff'd on rehearing, 295 F.2d 303 (7th Cir. 1961); cases cited notes 40-11 infra. In Holland Furnace, the respondent manufactured furnaces in one state and distributed them in 44 others. It sought to avoid FTC jurisdiction over the unfair and deceptive sales technique used by its own door-to-door salesmen by setting up scparate warehouses and sales organizations in each state and by filling every order from a warehouse in the state of sale. The company urged that since each furnace was in inventory before the unfair acts connected with its sale were committed, the FTC lacked jurisdiction because the furnaces had "come to rest." The court, however, upheld jurisdiction on two theories, discussed in notes 40 and 41 infra.

40. The court found jurisdiction on the theory that there is "no logieal point between shipment .... and delivery of Holland's products through its emplojees to the ultimate consumer when ... [the furnaces] cease to be in interstate commerce." Holland Furnace v. FTC, 269 F.2d 203, 210 (7th Cir. 1959). Previously, however, warchousing in the state where an unfair act occurred was considered to bring the goods to rest, whether or not the perpetrator was an interstate firm. Canfield Oil v. FTC, 274 F. 571, 573-74 (Guh Cir. 1921); Ward Baking Co. v. FTC, 264 F. 330 (2d Cir. 1920). The court, in Holland Furnace, however, rejected warehousing as the point where the goods came to rest because Holland's interstate shipments were dependent upon its own sales effort which followed warehousing. Holland Furnace v. FTC, supre at 210. Therefore, Holland Furmace scts up a separate test for goods coming to rest in cases where the sales outlet is owned by thic interstate shipper. Thus, jurisdiction depends upon whether the sales outlet is interstate in nature, not whether the goods had come to rest according to traditional tests.

Sun Oil Co. v. FTC extended Holland Furnace to cases where a manufacturer with a multi-state distribution system engages in unfair acts in only one state. $350 \mathrm{Fad} 624$ (7th Cir. 1965), cert. denied, 382 U.S. 982 (1966).

41. Holland Furnace Co. v. FTC, 269 F.2d 203, 212-13 (7th Cir. 1959). Alternatively; the court found that Holland's sales activities "had such a close and substantial relationship to interstate commerce as to bring them within the . . . jurisdiction of the Federal Trade Commission." Id. at 213. In other words, a frm's activities in intrastate commerce are regulable if they have a strong enough effect on its own interstate business. Thus, while Bunte Bros. holds that jurisdiction may not be based on an effect on a competitor's interstate business, Holland Furnace holds that jurisdiction may be based on an clicet on one's own interstate business. On this ground, Holland Fumace cites and follows Ford Motor Co. v. FTC, 120 F2d 175, 183 (6th Cir. 1941).

The Commission has urged that this ground brings within its jurisdiction the loal sales activities of a firm distributing in many states although the goods sold never travel between states. Bakers of Washington, 5 TrADE REc. REP. I 17,147 (FTC Dkt. 8309, 1964), aff'd on other grounds, sub nom. Safeway Stores, Inc v. FTC, 366 F.2d 795 (9th Cir. 1966), cert. denied, 386 U.S. 932 (1967). Jurisdiction was based on the close and substantial relationship between the sales efforts of the local branch and the interstate financial and management activities of the interstate corporate owners. This is clearly contrary to the traditional view that jurisdiction must be grounded on the interstate nature of the unfair act, not of the respondent's business. Canficld Oil v. FTC, 274 F. 5il (6th Cir. 1921). Nonetheless, it would be difficult to distinguish Bakers of Tashington and Folland Furnace for interstate financial and management activities are as mucl interstate commerce as interstate shipments of goods. In both cases, the interstate activity was wholly dependent upon the sales efforts of the local branch.

42. Holland Furnace Co. v. FTC, 269 F.2d 203, 210 (7th Cir. 1959). 
one state merely because it engages in interstate commerce in procuring its supplies. ${ }^{43}$

As to firms with sales outlets in only one state, all cases since Bunte $B$ ros. have involved unfair acts which were part of interstate commerce in the sense of the pre-Bunte Bros. cases. ${ }^{44}$ Jurisdiction will be upheld where the unfair act itself takes place across state lines. ${ }^{45} \mathrm{It}$ is no defense that the immediate impact of the interstate unfair act will be felt only in intrastate commerce. ${ }^{46}$ Jurisdiction also will be upheld if the unfair act takes place wholly within one state but is part of a transaction in interstate commerce. ${ }^{47}$ The transaction is considered to be in interstate commerce, first, if it takes place across state lines..$^{48}$ Second, an otherwise local transaction is in interstate commerce if it involves goods which had not yet "come to rest." 40 This may occur if a sales contract made with the use of unfair methods is executed by subsequently ordering goods from an out of state source..$^{50}$ Third, an otherwise local transac-

43. While the holding is not explicity limited to firms which distribute in scveral states, the court emphasized the national character of Holland Furnace's busincss and distinguished Bunte Bros. on this ground. Id. at 210. While the grounds for jurisdiction discussed in note 41 supra can be read to cover a firm with, for instance, management and procurement facilities in one state and warehousing and sales outlets in another, the logical cut-off seems to be multistate distribution. Otherwise, it would be difficult to distinguish the local drugstore which orders goods from the catalogue of an out of state wholesaler.

44. Cases cited notes 45.51 infra.

45. The following interstate acts have been held to be commerce: Advertising: Colgatc* Palmolive Co. v. FTC, 310 F.2d 89 (lst Cir. 1962), aff'd on other grounds, 380 U.S. 374 (1965); Bankers Securities Corp. v. FTC, 297 F.2d 403 (3d Cir. 1961); Progrcssive Tailoring Co. v. FTC, 153 F.2d 103 (7th Cir. 1946). Services: FTC v. Civil Service Training Bureat, Inc., 79 F.2d 113 (6th Cir. 1935). Shipment of lottery devices as part of scheme to make interstate sales of merchandise: Peerless Products, Inc. v. FTC, 284 F.2d 825 (7th Cir. 1960), cert. denied, 365 U.S. 844 (1961); Rosten v. FTC, 263 F.2d 620 (2d Cir. 1959); Scymour Sales Co. v. FTC, 216 F.2d 633 (D.C. Cir. 1954), cert. denied, 348 U.S. 928 (1955). Fraudulent requests for information to be used in collection of bad debts: National Clearance Bureau v. FTC, 255 F.2d 102 (3d Cir. 1958); Rothschild v. FTC, 200 F.2d 89 (7th Cir. 1953), cert. denied, 345 U.S. 941 (1953); Bernstein v. FTC, 200 F.2d 404 (9th Cir. 1952). Price Fixing Conspiracy: FTC v. Cement Institute, 333 U.S. 683 (1948).

46. Lichtenstein v. FTC, 194 F.2d 607 (9th Cir.), cert. denied, 344 U.S. 819 (1952); Globe Cardboard Novelty v. FTC, 192 F.2d 444 (3d Cir. 1951); Chas. Brown \& Sons v. FTG, 158 F.2d 74 (6th Cir. 1946). Lichtenstein, Globe Cardboard, and Chas. Brown is Sons upheld jurisdiction over interstate shipment of lottery devices to be used in stiles promotion in intrastate commerce. Salt Producers' Ass'n v. FTC, 174 F.2d 354 (7th $\mathrm{Cir} .1943$ ) (interstate price conspiracy to fix price of salt sold in intrastate commerce). See American News v. FTC, 300 F.2d 104 (2d Cir.), cert. denied, 371 U.S. 824 (1962) (interstate chain of newsstands buying and selling magazines in intrastate commerce induces discriminatory rebate from national publisher). Cf. S. Klein, 57 FTC 1543 (1960), complaint dismissed without explanation, 60 FTC 388 (1962) (advertising in interstate media by store selling only in intrastate commerce). The point at issue in S. Klein is potentially of great importance. Note, Interstate Dissemination of Advertising: Jurisdiction IWhich Must Be Earned, 38 IND. L.J. 455 (1963).

47. Cases cited in notes 48-5I infra.

48. Consumers Home Equipment Co. v. FTC, 164 F.2d 972 (6th Cir. 1947).

49. Ashville Tobacco Board of Trade v. FTC, 263 F.2d 502 (4th Cir. 1959) (unfair acts in the course of the operation of a commodity market).

50. Pacific States Paper Trade Ass'n v. FTC, 273 U.S. 52 (1927) (pre-Bunte Bros, case). 
tion is in interstate commerce if subsequent interstate shipment of the goods sold in the transaction is contemplated. This occurs mainly where the firm services a multi-state market through a large retail outlet located near a state border. Although the sale took place wholly within one state, the firm could foresee that a number of customers were likely to take or ship the goods across state lines. ${ }^{51}$

In sum, a firm servicing a one-state market is immune to regulation so long as any goods of interstate origin are within the state before the unfair act takes place and the facilities of interstate commerce are not used in perpetrating the unfair act. ${ }^{62}$ Thus, most concerns with a one state market are immune. Under the unchallenged holding of Bunte Bros., such a firm is not regulable simply because it competes with interstate firms.

\section{Bunte Bros.' Impact on Enforcement}

The holding in Bunte Bros. was based on the assumption that denying jurisdiction over local competitors of interstate firms would not frustrate the purpose of the act. ${ }^{.3}$ This assumption is erroneous today when the Commission relies so heavily on industry-wide voluntary compliance. ${ }^{54}$ This is well illustrated by a typical set of examples:

1) The Harris Rug Companys5 sells carpeting door-to-door in New Orleans and Southern Mississippi. Harris' sales techniques in Mississippi, but not Louisiana, are regulable ${ }^{5 B}$ because sales contracts are filled from a New Orleans warehouse. Harris and other interstate firms compete in the Mississippi market with several wholly local firms which, under Bunte Bros., are not regulable. ${ }^{57}$ Most of these firms sell good quality carpeting at less than the usual store prices. But all employ the unfair practice of misrepresenting the carpeting's usual retail price. ${ }^{58}$ The Commission has recently requested Harris and the other interstate firms to stop this deceptive practice in the Mississippi market.

51. Bankers Securities Corp. v. FTC, 297 F.2d 403 (3d Cir. 1961).

52. Since all of the 29 jurisdictional cases since Bunte Bros. which reached the courts of appeal were decided in the Commission's favor, it is difficult to state precisely what is not regulable.

53. See p. 1691 supra.

54. See notes $3-5$ supra.

55. Harris' name, product, and market have been altered, but in other respects this example is real.

56. Cases cited notes 43 \& 50 supra; Hill Bros. v. FTC, 9 F.2d 481, 484 (9th Cir. 1929) (dictum).

57. Harris may not defeat FTC jurisdiction by showing it competes with unregulable firms. Royal Oil Corp. v. FTC, 262 F.2d 741, 744 (4th Cir. 1959).

58. The court held that this is an unfair practice in Bankers Securities Corp. v. FTC, 297 F.2d 403 (3d Cir. 196I). 
Harris is presented with two unattractive choices: comply or litigate. Harris would be willing to comply but for the prospect of losing business to the unregulable Mississippi firms. Furthermore, if deprived of their normal sales pitch, Harris' salesmen, who are paid on a commission basis, will switch to the Mississippi firms. On the other hand, Harris could buy a few extra years of higher profits by litigating.

The situation is no happier from the Commission's point of view. If Harris decides to fight, all of its interstate competitors probably will as well. The Commission may then drop the enforcement program because its limited resources can be better spent where market-wide voluntary compliance can be achieved with only the threat of a formal proceeding. ${ }^{59}$ If Harris and its interstate competitors comply, voluntarily or after litigation, the Commission has achieved little. Harris will concentrate on the New Orleans market where the unfair practice can continue unchecked. Meanwhile, the interstate firms will lose many sales in Mississippi to their local competitors who continue the unfair practice. In either event, the public has received little protection.

2) In contrast, neither discrimination against regulable firms nor inadequate consumer protection results when the Commission has jurisdiction over all the competitors in the market. In the District of Columbia, where the Commission has jurisdiction over all firms, the discount furniture stores customarily misrepresented usual retail prices in newspaper advertisements. The Commission requested all of them to cease this unfair practice. Each complied without litigation because their competitors could be forced to comply. ${ }^{60}$

Unfortunately, the Harris Rug example is not an isolated case. Enforcement often is hindered where regulable and unregulable firms compete. Such competition occurs in many types of markets.

1. A manufacturer, mail order house, or door-to-door sales company distributing in one state competing with firms distributing in several states,

2. A local retailer or wholesaler competing with the local branch of an interstate firm, and

3. A local retailer drawing customers from one state competing with a store drawing customers from several states.

59. Note the list of factors cited in the Report accompanying the letter from Paul Rand Dixon, Chairman of the FTC, to Senator Warren Magnuson, Dec. 21, 1965, at 14.15. If the Commission allocates its given resources to maximize compliance, it would be ex. pected not to police relatively small markets where litigation is likely. Once a compliance program has begun and the prospect of litigation arises, however, it may procecd anyway, in order to maintain its credibility.

60. 1960 FTC ANN. REP. 3. 
The Commission considers the lack of jurisdiction over local competitors of regulable firms a serious problem, yet has found no workable, general solution. A commentator noted in 1961 that

The Commission has recently expressed an intent to police the local competitior where its activities interfere with Commission efforts to stop questionable methods on an industry-wide basis. ${ }^{61}$

The Commission has, in fact, often gained jurisdiction over ostensibly local firms on the basis of inconsequential amounts of interstate sales. ${ }^{62}$ But such technical grounds for jurisdiction can be found in only a limited number of cases.

In 1965, the Commission attempted to cope with the problem by encouraging states to regulate the local competitor. ${ }^{13}$ Chairman Paul Rand Dixon indicated that the Commission had appointed an Assistant General Counsel for Federal-State Cooperation in order to

provide more adequate governmental protection against [local] selling practices which victimize ... the honest competitor

by closing the gap between Federal and State regulatory activity. of

While this intergovernmental cooperation is commendable, it provides no solution. The states still show little interest in enacting or enforcing legislation commensurate to the Federal Trade Commission Act passed over a half century ago. ${ }^{\text {"5 }}$ Even if state enforcement were adequate, however, industry-wide voluntary compliance programs in markets where regulable and unregulable firms compete would be diffcult to implement because they would require the continuous agreement and coordination of the FTC and one, or perhaps many, state agencies.

The Commission has not sought to solve the problem by urging that Bunte Bros. be limited. This probably stems from a desire to maintain its record of having won each of the 29 jurisdictional cases since Bunte Bros. The Commission, by thus avoiding a precise definition of its jurisdiction, has maintained its ability to bluff firms into voluntary compliance in questionable cases. ${ }^{60}$ Nonetheless, the Commission would

61. McKinney, The FTC is Eyeing Local Business Activily, 49 ILL. B.J. 734, 740 (1961).

62. E.g., Safeway Stores Inc. v. FTC, 366 F.2d 795, 798-99 (9th Cir. 1960).

63. FTC News Release, July 7, 1966, and April 3, 1965, and statement of Senator Harrison Williams attached to FTC News Release of April 8, 1965.

64. Report accompanying letter from Paul Rand Dixon, Chairman of the FTC, to Senator Warren Magnuson, Dec. 21, 1965, at 38.

65. Although a surge of state interest has been reported, state laws are generally far less strict and are enforced less strenuously. Id. 37 .

66. A violator's belief that the Commission has a reasonable chance of succeding in formal proceedings is naturally crucial in inducing voluntary compliance through in-
formal methods. 
appear to have a good chance of success, even within the terms of Frankfurter's canon of statutory interpretation. ${ }^{67}$ First, Bunte Bros. at least partially frustrates the purpose of the Act. Second, there is compelling evidence, for some reason never used in the Bunte Bros.' opinions or briefs, that Congress actually did intend to grant jurisdiction coterminous with the commerce power.

\section{Legislative History}

The original bills passed by the House and Senate defined commerce as "such commerce as Congress has the power to regulate." 08 If this language had been retained by the Conference committee, there would be no question that jurisdiction was meant to be coextensive with the commerce power. The Conference bill, however, changed the definition to read:

"Commerce" means commerce among the several States [and commerce relating to foreign countries and certain territories].60

Yet the debates, ${ }^{70}$ together with the report of the House Conference managers, ${ }^{71}$ imply that the change was made solely to exclude Guam, the Canal zone, and the Philippines from jurisdiction. Furthermore, if Congress intended to restrict jurisdiction, the words "commerce among the several States" were poorly suited to its purpose. Only a year before, the Supreme Court had reiterated Chief Justice Marshall's statement from Gibbons v. Ogden that "commerce among the several States" includes "that commerce which concerns more states than one."72 Also, at the time, the Sherman Act language, "restraint of trade or commerce among the several States," was read to be coterminous with the commerce power..$^{73}$ Furthermore, if Congress intended to limit jurisdiction, it could have easily achieved this purpose by using language such as "commerce between any of the several States." 74 Frankfurter's insistence on the use of "affecting commerce" to grant jurisdic-

67. See p. 1691 supra.

68. H.R. REP. No. 1142, 63d Cong., 2d Sess. 11, 13 (1914).

69. Id. 2 .

70. 51 Cong. REc. 14927 (1941) (remarks of Congressmen Sherley and Covington), 14095 (remarks of Congressmen Willis and Stevens).

71. H.R. REP. No. 1142 supra note 68 , at 18.

72. Gibbons v. Ogden, 22 U.S. (9 Wheat.) 1, 194 (1824); The Minnesota Rate Cases, 230 U.S. 352, 398 (1913).

73. See, e.g., United States v. American Tobacco Co., 221 U.S. 106, 175-76, 180 (1911). Also, several pre-Bunte Bros. cases stated that $\S 5$ jurisdiction extends over acts which merely affect interstate commerce. See, e.g., Chamber of Commerce v. FTC, 13 F.2d 673, 684 (8th Cir. 1926).

74. Such language is used in 45 U.S.C. $\S 51$ (1964). 
tion coextensive with the commerce power mistakes the language thought necessary at the time to convey this meaning.

\section{Conclusion}

While the legislative history provides sufficient basis for reading the grant of jurisdiction broadly, it is unlikely that the Court would completely overrule Bunte Bros. To do so would, under recent interpretations of the commerce power, give the Commission jurisdiction over almost all business. ${ }^{75}$ Even if the Commission desired such a wide domain, it lacks the manpower to police it. ${ }^{70}$ In addition, such a drastic increase in jurisdiction goes well beyond what is needed to achieve an effective voluntary compliance program. For instance, jurisdiction is not needed over the many local firms which affect commerce only through buying goods of interstate origin or supplying goods to persons or firms engaged in interstate commerce. Nor is jurisdiction required over all competitors of presently regulable firms.it The Commission should therefore urge that Bunte Bros. be limited, but only to the extent necessary to get jurisdiction over those local competitors which must be regulated to achieve an effective voluntary compliance program.

The Shreveport Rate Case ${ }^{i 8}$ provides a useful test with which to identify these local competitors. There it was held that intrastate commerce could be regulated

Wherever the interstate and intrastate transactions ... are so related that the government of one involves the control of the other. ... ${ }^{\text {79 }}$

Analogously, the Commission should be allowed to prohibit unfair practices in intrastate commerce where their continued use is likely to frustrate the industry-wide voluntary compliance program in stopping or deterring unfair acts in interstate commerce. The Commission could determine the likelihood of a local firm's unfair practice affecting the behavior of the interstate firm by looking to such factors as the size of the loss which the unfair practice's continued use would inflict on the honest competitor and the importance of this loss to his overall profits.

75. E.g., Katzenbach v. McClung, 379 U.S. 294, 299 (1964).

76. The less than four million dollars currently allocated to consumer protection allow only selective enforcement. 1965 FTC ANN. REP. 2, 11.

77. Jurisdiction would not be needed over competitors whose unfair acts inflict only insubstantial losses on regulable firms.

78. Fouston, E. \& W. Texas RY. v. United States, 234 U.S. 342, 350.55 (1914).

79. Id. at 351 . 
This test would therefore exclude local competitors from regulation unless the unfair practices actually used seriously damaged presently regulable firms. ${ }^{80}$

Stare decisis should be no obstacle to upholding jurisdiction over local competitors where necessary for effective functioning of the industry-wide voluntary compliance program. Bunte Bros. might be distinguished on the theory that it was neither alleged nor shown there that that jurisdiction over the local competitor was necessary to regulate the interstate firms. Rather, the Commission sought jurisdiction over all local business which injures interstate commerce. ${ }^{81}$ If Bunte Bros. is not thought to be distinguishable, there is good cause to overrule it. Experience has shown that the rule of Bunte Bros., in connection with such changing conditions as the Commission's greatly increased reliance on industry-wide voluntary compliance, has often made enforcement impossible. ${ }^{82}$ On the other hand, no identifiable group has relied on Bunte Bros. ${ }^{83}$ Nor would the respondent firm in the limiting case be victimized, since the resultant cease and desist order would have only prospective application. ${ }^{84}$ Not limiting Bunte Bros. to the extent suggested here would seem inconsistent with Holland Furnace and related cases which have, for reasons of sound policy, upheld jurisdiction over local business activity which affects interstate commerce in a particular well-defined way. ${ }^{85}$

Section 5 of the Act can properly be interpreted to grant jurisdiction over the local competitor whose continued use of an unfair practice frustrates industry-wide enforcement. Such an interpretation extends the FTC's jurisdiction only marginally and does not unduly upset the "proper adjustment of the local and national interests in our federal scheme."80

80. Although $\$ \mathbf{5}$ incorporates the public policy of the Sherman, Clayton, and Robin. son-Patman Acts, (note 2 supra), this suggested increase in $\$ 5$ jurisdiction would not indirectly increase the sweep of these other laws as the industry-wide voluntary compliance program is directed mainly at deceptive practices, Report from Paul Rand Dixon to Senator Magnuson, supra note 64 , at 17 , which are not violations of other federal legislation.

81. Brief for Petitioner at 6, FTC v. Bunte Bros., 312 U.S. 349 (1941).

82. See notes $3 \cdot 6$ supra.

83. Courts are particularly likely to adhere to stare decisis where an identifiable group has acted in reliance on the precedent. Cf. Toolson v. New York Yankees, 346 U.S. 356, 357 (1953).

84. FTC Act § 5(b), 15 U.S.C. § 45(b) (1964).

85. See cases cited in notes $39-41$ supra.

86. FTC v. Bunte Bros., 312 U.S. 349,351 (1941). 